\title{
The structure of local government financial information systems: the case of very early XXI century US
}

\author{
Wojciech A. Nowak*
}

\begin{abstract}
Purpose - the main objective of this paper is to unfold the cognitive patterns and models developed for local government authorities financial information in the US, and their potential universality. Design/Methodology/Approach - the general mode is of descriptive-analytical nature. As the specific point of time for descriptions and analyses, the year 2005 has been chosen, i.e. the first full year of the presence of Poland within the European Union structures, and the starting point for the contemporary evolution of Polish accounting within Western World. As research tools, the approaches of the contingency theory of organizations and the enterprise governance framework have been used. Objectives and models for local government authorities general financial information have been conceived through the lens of local government financial reporting. Findings - consequently, it can be stated that within the American picture of the world, this kind of reporting is oriented towards stakeholders not-in-power to execute individually information on entity's states and performance, and is guided by accountability and decision-making usefulness. It should be pointed that within Polish picture of the world, this kind of reporting is mainly oriented towards stakeholders in-power to execute individually information on entity's states and performance, and accountability and decisionmaking usefulness is guided by two perspectives, i.e. political perspective and economic perspective. The political perspective covers a local government budget, and the economic perspective covers local government entities management, especially financial management. The objectives and models - and the way of their establishing and regulating - for the American picture of the world have been presented. Originality/Value there is a lack of comparative researches that undertakes the question of Anglo-American financial reporting models universality. This paper contributes to narrowing the gap. The reached results seem to testify for the considerable level of the universality of American approaches and models, and are of especially overtone in the context of expected European Public Sector Accounting Standards (EPSAS).
\end{abstract}

Keywords: financial information systems, local government, territorial self-government, comparative research, American models universality, public sector accounting

\section{Introduction}

The issue of objectives and models of local government financial reporting is viewed in this paper as part of broader issue of regulating the mode of local communities existence and development. This mode is affected by the picture of the world - strictly speaking by the relational subsystem of the picture (Fleischer 2002: 381, 388) - generated and employed by the society and the communities. Thus understood picture of the world comprises, among other things, organizational governance structures and specifically conceived contingencies.

* prof. nadzw. UŁ dr hab. Wojciech A. Nowak, Uniwersytet Łódzki, Katedra Rachunkowości, ul. Matejki 22/26, 90-237 Łódź, e-mail: wanowak@uni.lodz.pl. 
The paper presents modern materializations of approaches to the preparation and use of accounting representations of local government financial condition and performance as well as service efforts and accomplishments. The example presented is from the US. As the specific point of time, the year 2005 was chosen, i.e. the first year of the presence of Poland within the European Union structures, and the starting point for the evolution of Polish accounting within Western world.

\section{Local government reporting in the light of contingency approach and enterprise governance approach}

In the strict sense, contingency occurs when the relation between the variable $\mathrm{X}$ and the variable $\mathrm{Y}$ depends on a third variable $\mathrm{W}$, which conditions and moderates this relation. Thus, the variable $\mathrm{W}$ can be called a moderator or a conditioning variable ${ }^{1}$. By conditioning the relation between two elements, the moderator also conditions the mode of their existence.

In the case of consolidated information we are dealing with the relation between a local authority, functioning as an organization, and a set of its stakeholders (external stakeholders in particular) ${ }^{2}$. It is a relationship oriented towards amplification of the welfare of each of its elements, that is both the organization and its stakeholders. It is an acknowledged fact that a factor conditioning this relation is financial and non-financial information about the condition and performance of local governments viewed as organizations, taking in practice the form of reporting. The factor conditioning a relation (i.e. consolidated information) is a contingency ${ }^{3}$. Such a situation is illustrated in Figure 1.

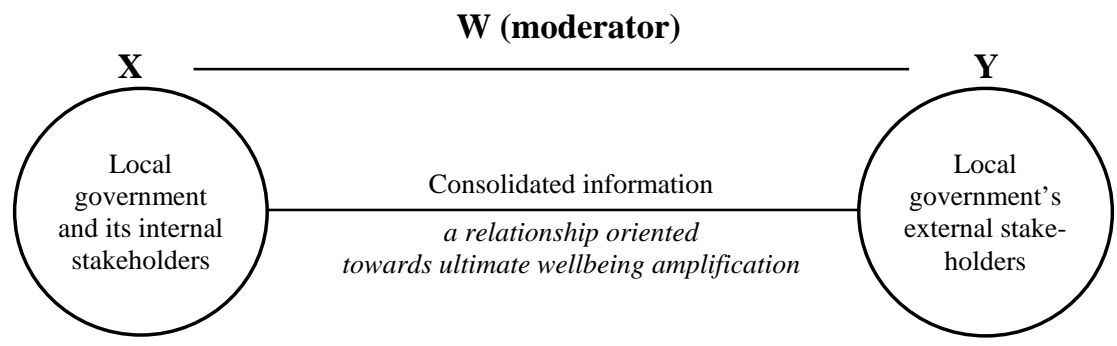

Figure 1. Consolidated information as contingency

Source: author's research.

For the sake of comparability of information it should be generated and processed according to fixed rules, i.e. it should be standardized. Hence the need for standards regulating its generation, structuring and publication. The entity generating, structuring and publishing information about organization is organization itself. Therefore what we are dealing with is self-description of an organization.

\footnotetext{
${ }^{1}$ After Donaldson (2001: 5-6).

${ }^{2}$ The organization is treated here as the collection of human and non-human resources, aiming at the specified goal. From this perspective, internal stakeholders are an integral part of the organization.

${ }^{3}$ Compare Donaldson (2001: 7).
} 
Generally, the internal framework of organizational self-description is determined by the governance processes. Today, the most comprehensive structure of organizational governance is based on the concept of enterprise governance, which constitutes a holistic framework for the self-description. This framework comprises both the aspect of conformity with norms regulating the relations, and the aspect of performance conforming to these norms (see Figure 2). In such a context local government consolidated information should cover both conformance aspect of and performance aspect.

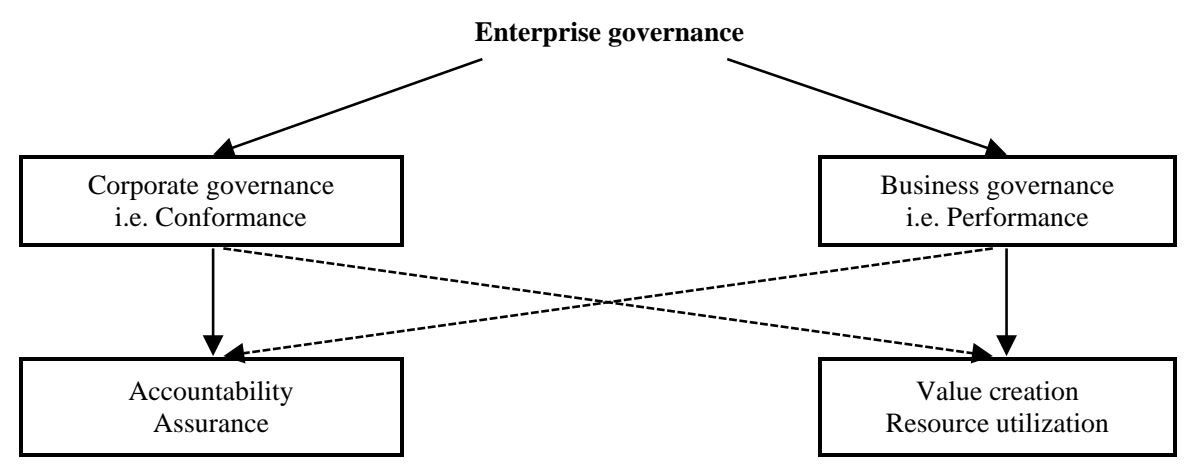

Figure 2. The enterprise governance framework

Source: IFAC EG (2004: 10).

The author is convinced that both concepts, i.e. the contingency concept and enterprise governance concept constitute - explicite or implicite - the general framework of generating, structuring and presenting local government consolidated information.

To illustrate this thesis, we will now examine the goals and models of local government consolidated financial information in the light of the US regulations.

\section{Objectives and models of local government consolidated information in the American picture of the world}

To identify objectives and models of local government consolidated information we take into account the US approach. The US system of government consists of three tiers: federal, state and local with respectively federal, state and local authorities. The authorities are viewed as complex economic entities with internal and external stakeholders interested in their condition and performance. It is generally accepted that in a democratic society financial reporting has a great role in public authorities accountability to the society. Generation and communication of information on their condition and performance is regulated in the US by relevant standards based on a formalized conceptual framework.

The conceptual framework and standards for the federal level are formulated by the Federal Accounting Standards Advisory Board (FASAB); the state and local levels are regulated by the Governmental Accounting Standards Board (GASB). The conceptual frameworks and standards formulated by GASB relate to general purpose external financial reporting (USGASBCS 1), which has as its part reporting on the efforts and accomplishments in the area of services (US GASBCS 2). 
It should be noted that special purpose financial reporting, i.e. reporting oriented to specific needs of specific users ${ }^{4}$, is outside GASB competence. It is also important to note that the shape of public authorities financial reporting is influenced by the specificity of American governmental system. The main features of this system have been identified (US GASBSC 1: para 13) as follows:

1. Structural characteristics of government and the type of services provided:

a) the form of government as representation of society and division of authority;

b) federal system of government and predominance of intergovernmental revenues;

c) connection between the taxpayers and the services supplied to them.

2. Regulatory characteristics, implied by the structure of government:

a) budget as an expression of public policy and financial intentions and a method of achieving controllability;

b) the use of fund accounting for regulatory purposes.

3. Specific features:

a) apparentness of similarity of identically designed authorities,

b) substantial investment in capital assets not generating revenue,

c) the nature of political process.

\subsection{State and local authorities as reporting entity}

In GASB conceptual framework external financial reporting generally applies to state and local entities (US GASBCS 1, preface US GASBCS 2: para 12). A special standard addresses the issue of identifying the financial reporting entity - Standard No. 14 GASB "Financial reporting entity" (US GASB 14). It provides (ibid.: para 10) that at the state and local levels the basis for identification of a reporting entity is obligation to be accountable. On this basis the state and local level financial reporting entity has been defined to comprise (ibid.: para 12):

a) the primary authority (i.e. an authority having legal personality and elected governing body, and financially independent of other state or local authorities);

b) organizations whose financial activity is accounted for by the primary authority;

c) other organizations, tied with the primary authority by such specific relationships that leaving them out would result in incomplete or incorrect financial statements.

Normally the central unit of thus defined reporting entity is the primary authority, although other organizations making up the reporting entity may issue their own financial statements.

There are three groups of primary users of state and local government external financial reporting (US GASBCS 1: para 30):

a) those to whom authorities are accountable in the first place (the group of citizens sensu largo, including citizens sensu stricte, media, advocate groups and public finance researchers);

b) those who directly represent citizens (legislative and supervisory bodies);

\footnotetext{
${ }^{4}$ According to (US GASBSC 1: para 7), special purpose financial reporting is mainly applied in order to: a) meet specific requirements of law or contracts; b) present financial statements using measurement bases not included in the sets of generally accepted accounting principles; ; c) present financial information in prescribed formats; d) report on prescribed elements, accounts or items of general purpose financial statements.
} 
c) lenders or participants of the lending process (the group of investors and creditors) ${ }^{5}$.

\subsection{Objectives of state and local government general purpose financial reporting}

It is assumed that in democratic society the citizen "has the right to know"6 (US GASBCS 1: para 56), and governmental financial reporting should provide information assisting its users in the evaluation of a reporting entity's accountability ${ }^{7}$ and in making economic, social and political decisions (ibid.: para 32), with emphasis on public accountability (ibid.: para 76).

It is also assumed that external financial reporting utility is realized through its use for (ibid.: para 32):

- comparing actual financial results with statutorily adopted budget,

- assessing the financial position of an accounting entity and its operating results,

- determining conformity with rules, principles and any regulations relating to the financial sphere,

- evaluation of efficiency and effectiveness.

In this context the following goals of governmental financial reporting have been formulated (ibid.: para 77, 78, 79):

1. Supporting authorities in their public accountability and enabling users of financial statements to assess how this obligation is discharged.

In this connection financial reporting should:

a) provide information for determining whether the current year's revenues were sufficient to pay for this year's services;

b) demonstrate the degree of compliance of the sources and uses of funds with the adopted budget;

c) provide information assisting users in assessing the efforts, costs and results of the service activity of a given entity.

2. Assisting the users of financial statements in assessing the operating results for a financial year.

Therefore financial reporting should provide information:

a) on the sources and uses of funds;

b) on methods of financing the activities and raising cash;

c) enabling a determination whether the financial position of an entity was strengthened or weakened as a result of operations carried out in a given year.

3. Assisting the users in assessing the volume of services to be provide by a given entity and its ability to meet the obligation when due.

Therefore financial reporting should:

a) provide information on the financial position and condition of the entity;

\footnotetext{
${ }^{5}$ The executives having access to financial data through internal reporting are not classified among the main users of external reporting, although obviously they make use of it in various ways.

${ }^{6}$ This is the right to obtain openly declared information about facts which may give rise to public debate between citizens and their elected representatives.

${ }^{7}$ Which is meant to constitute a basis for justifying the accumulation of public resources and their uses.
} 
b) provide information on the entity's non-financial (including physical) resources with useful lives exceeding the current year, together with information necessary for assessing the service potential of these resources;

c) disclose statutory or contractual restrictions concerning the resources or the risk of their potential loss.

Financial reporting is supplemented by reporting on the efforts and accomplishments in the area of service provision. This kind of reporting is supported by the Conceptual Declaration No 2 "Service efforts and accomplishments reporting" promulgated by GASB (US GASBCS 2: 1994). The aim of this reporting is to support its users in evaluating the economy, efficiency and effectiveness of the services provided by a particular entity through supplying information on its performance that is not covered by financial reporting.

It should be noted that US GASB conceptual statements show great conceptual similarity to the conceptual statements by US FASB, especially to the conceptual statements on objectives of financial reporting by business enterprises (US FASBCon 1), on objectives of financial statements of nonbusiness organizations (US FASBCon 4), and on qualitative characteristics of accounting information (US FASBCon 2).

\subsection{The way of achieving the objectives of state and local government general purpose financial reporting}

The objectives of state and local government public accountability are realized through publication of financial reports and information on the performance in the area of services provision. Financial statements are the primary element in this system.

General purpose financial reporting comprises (US GASBCS 1: para 6):

- general purpose financial statements,

- simplified or "popular" financial reports (lower level of detail and more condensed than general purpose financial statements),

- comprehensive annual financial reports, containing detailed information.

Simplified reports and comprehensive annual reports may also contain non-financial information such as statistical data, analytical data, economic and service delivery statistics, demographic information, prognostic information, data on service efforts and accomplishments, data required by law, explanations in narrative form and graphic information. Data on service efforts and accomplishments should include measures relating to service efforts (input indicators), accomplishments measures (outputs and outcome indicators), measures relating efforts and accomplishments (efficiency cost-outcome indicators) and explanatory information.

Under GASB Standard No 34, general purpose financial reporting should include at least (US GASB 34: para 6):

a) introductory information to financial statements and analytical review of the authority's financial activity (prepared by the executives of the reporting entity);

b) basic financial statements, consisting of:

- comprehensive consolidated financial statements, covering overall activity of the authority (with the exception of the fiduciary activity), i.e. so called governmentwide financial statements, 
- $\quad$ fund statements ${ }^{8}$,

- notes to financial statements;

c) obligatory additional information other than introductory information and analytical review.

Reporting is to be based on fund accounting (US GASBSC 1: para 13, 21, 22) oriented to the measurement - depending on the type of fund - of, respectively, the economic resources and using the accrual accounting, or current financial assets and using modified accrual accounting (US GASB 34: para 16, 79, 107). Consolidated financial statements are oriented to measurement of economic resources and use accrual accounting (US GASB 34: para 16).

In comprehensive consolidated financial statements, information about the primary authority as a whole and information about the units making it up should be put in separate lines and columns. A distinction should be made between governmental-type activity ${ }^{9}$ and business-type activity ${ }^{10}$ (US GASB 34: para 14 and 15).

The obligatory components of consolidated financial statements are the following (US GASB 34: para 13), (US GASB 34: AppendixA-1, Appendix B-1):

- statement of net assets, i.e. balance-sheet,

- statement of (costs and revenues of) activities, i.e. a special form of profit and loss account.

The required set of fund statements depends on its type. The set consists of the following statements:

- fund balance-sheet,

- statement of revenues, expenses and changes in fund balances,

- statement of changes in fund net assets or statement of changes in fund equity (de facto a specific form of profit and loss account),

- statement of fund cash flow.

The information presented in general purpose financial reports has to be of due quality, i.e. have the following qualities (US GASBSC 1: para 62-68; US GASBSC 2: para 57-66): a) comprehensibility, b) reliability, c) relevance, d) timeliness, e) consistency, f) comparability.

In normal conditions the balanced combination of these qualities is achieved using the "cost-benefit" criterion, as well as estimated values for part of the data and specific rules for their processing. It should be noted that the perception of the qualitative features of information in financial statements will depend on the particular economic and political situation (US GASBSC: para 69-73; US GASBSC 2: para 67).

In US practice the objectives of governmental financial reporting are achieved by issuing annual financial reports consisting of a prescribed set of comprehensive consolidated financial statements, fund statements and additional information including the service efforts and accomplishments. In consolidation the primary entity is not accounted for sepa-

\footnotetext{
8 “A fund is defined as a fiscal and accounting entity with a self-balancing set of accounts recording cash and other financial resources, together with all related liabilities and residual equities or balances, and changes therein, which are segregated for the purpose of carrying out on specific activities or attaining objectives in accordance with special regulations, restrictions, or limitations.” (US NCGAS 1: para 16).

${ }^{9}$ I.e. activity financed from taxes, intergovernmental flows of funds and other revenues.

${ }^{10}$ I.e. activity financed whole or partly from payments made by outside parties for goods and services provided for them.
} 
rately - however presentation is focused on primary authorities as a whole, with a separate column with data summarizing component units of primary authorities. This set presents both financial states and results and non-financial performance (service efforts and accomplishments). The aim of the promulgation of GASB standards to be applied in financial statements preparation is to enable the fulfillment of financial reporting objectives.

Admittedly, the objectives and models of American state and local government reporting are characterized by considerable complexity and specific terminology, which impedes their perception by non-Americans. However, general ideas of the American approach can be relatively easily implemented by means of the business model of financial reporting. For this reason is has become the inspiration to other systems, which is apparent, for example, in New Zealand's approach to governmental reporting.

\section{Conclusion}

The analyses carried out in the paper points out to the deep rationality of cognitive patterns and models developed within the American approach, and the possibility of using them in our exploration of the reality. The application of these constructs to the local authorities financial accounting and reporting contributes to creating a basis for the shaping of relevant development directions. The results seem to testify for American approaches and models considerable universality, and are of especially importance in the context of expected European Public Sector Accounting Standards (EPSAS).

\section{References}

Donaldson L. (2001), The contingency theory of organizations, Sage Publications, Thousand Oaks, London/New Delhi.

Fleischer M. (2002), Teoria kultury i komunikacja: Systemowe i ewolucyjne podstawy, Dolnośląska Wyższa Szkoła Edukacji Towarzystwa Wiedzy Powszechnej, Wrocław (originally edited in German: Fleischer M. (2001), Kulturtheorie - systemtheoretische und evolutionäre Grundlagen, Athena-Verlag, Oberhausen).

Nowak W.A. (1998), Rachunkowość sektora publicznego: Koncepcje, metody, uwarunkowania, Wydawnictwo Naukowe PWN, Warszawa.

Nowak W.A., Bakalarska B. (2001), Polish public sector accounting in transition: The landscape after early 1999 step in the State redefining, in: International Comparative Issues in Government Accounting: The similarities and differences between central government accounting and local government accounting within ot between countries, ed. A. Bac, Kluwer Academic Publishers, Boston/Dordrecht/London.

Nowak W.A., Bakalarska B. (2005), The model of financial reporting for local government: Methodology for international comparisons and some cases' analyses, in: International trends and experiences in government accounting, eds A. Boumistrov, F. Mellemvik, Cappelen Akademisk Forlag, Oslo.

Ustawa o finansach publicznych z 1998 r., z póź. zm. (1998 Public finance act, as amended), PL UFP (1998).

Ustawa o finansach publicznych z 2005 r., z późn. zm., (2005 Public finance act, as amended), PL UFP (2005).

Statement of Financial Accounting Concepts No. 1: Objectives of Financial Reporting by Business Enterprises, US FASBCon 1, November 1978, Norwalk, CT.

Statement of Financial Accounting Concepts No. 2: Qualitative Characteristics Of Accounting Information, US FASBCon 2, May 1980, Norwalk, CT.

Statement of Financial Accounting Concepts No. 4: Objectives of Financial Reporting by Nonbusiness Organizations, US FASBCon 4, December 1980, Norwalk, CT.

Concepts Statement No. 1 of the Governmental Accounting Standards Board: Objectives of Financial Reporting, US GASBSC 1, May 1987, Norwalk, CT.

Concepts Statement No. 2 of the Governmental Accounting Standards Board: Service Efforts and Accomplishments Reporting, US GASBCS 2, April 1994, Norwalk, CT. 
Statement No. 41 of the Governmental Accounting Standards Board: The Financial Reporting Entity, US GASBS 14, Norwalk, CT.

Statement No. 34 of the Governmental Accounting Standards Board: Basic Financial Statements - and Management's Discussion and Analysis - for State and Local Governments, US GASBS 34, June 1999,Norwalk, CT.

National Council on Governmental Accounting Statement 1: Governmental Accounting and Financial Reporting Principles, in: Original Pronouncements: Governmental Accounting and Financial Reporting Standards as of June 30, 2003, Governmental Accounting Standards Board, US NCGAS 1, March 1979, Norwalk, CT.

\section{STRUKTURA SYSTEMÓW INFORMACJI FINANSOWEJ WLADZ LOKALNYCH: PERSPEKTYWA USA POCZĄTKÓW XXI WIEKU}

Streszczenie: Cel - głównym celem artykułu jest odkrycie wzorów i modeli poznawczych, rozwiniętych w Stanach Zjednoczonych, w obszarze systemów informacji finansowej władz lokalnych, oraz skierowanie uwagi na ich potencjalną uniwersalność. Metodologia badania - przyjęta metoda ma zasadniczo charakter deskryptywno-analityczny. Jako specyficzny moment dla opisów przyjęto rok 2005, czyli pierwszy pełny rok uczestnictwa Polski w strukturach Unii Europejskiej, będący punktem startu współczesnej ewolucji polskiej rachunkowości w ramach świata zachodniego. Jako narzędzia badawcze wykorzystano kontyngencyjną teorię organizacji oraz konceptualną ramę kolektywnego władania (corporate governance). Cele i modele ogólnej informacji finansowej władz lokalnych ukazano przez pryzmat ich sprawozdawczości finansowej, wraz ze sposobami ich określania i regulacji, charakterystyczne dla danego obrazu świata. Wynik - można stwierdzić, że - w ramach amerykańskiego obrazu świata - ogólna sprawozdawczość władz lokalnych zorientowana jest na interesariuszy niemających indywidualnej mocy wyegzekwowania informacji o położeniu i wynikach owych władz, oraz że kierunkowana jest na wyliczanie się wobec tych interesariuszy (accountability) i na użyteczność przy formułowaniu przez nich decyzji (decision-making usefulness). Wskażmy, iż w ramach polskiego obrazu świata, sprawozdawczość ta pozostaje zorientowana głównie na interesariuszy zdolnych indywidualnie wyegzekwować informację o położeniu i wynikach jednostki sprawozdawczej, zaś wyliczanie się i użyteczność decyzyjna kierunkowane są z dwóch perspektyw, to jest z perspektywy politycznej i perspektywy ekonomicznej. Perspektywa polityczna obejmuje budżet władz lokalnych, a perspektywa ekonomiczna zarządzanie ich podmiotami ekonomicznymi, w szczególności zarządzanie finansowe. Oryginalność/Wartość - generalnie, w świecie brakuje naukowych badań porównawczych podejmujących kwestię uniwersalności amerykańskich modeli sprawozdawczości finansowej. Artykuł przyczynia się do ograniczenia tego braku. Uzyskane rezultaty zdają się potwierdzać uniwersalność amerykańskich podejść i modeli sprawozdawczych, co ma szczególny wydźwięk w kontekście oczekiwanych ogólnounijnych europejskich standardów rachunkowości sekatora publicznego (EPSAS).

Slowa kluczowe: systemy informacji finansowej, władze lokalne, samorząd terytorialny, badania porównawcze, uniwersalność modeli amerykańskich, rachunkowość sektora publicznego

\section{Cytowanie}

Nowak W.A. (2015), The structure of local government financial information systems: the case of very early XXI century US, Zeszyty Naukowe Uniwersytetu Szczecińskiego nr 873, „Finanse, Rynki Finansowe, Ubezpieczenia” nr 77, Wydawnictwo Naukowe Uniwersytetu Szczecińskiego, Szczecin, s. 267-275; www.wneiz.pl/frfu. 
